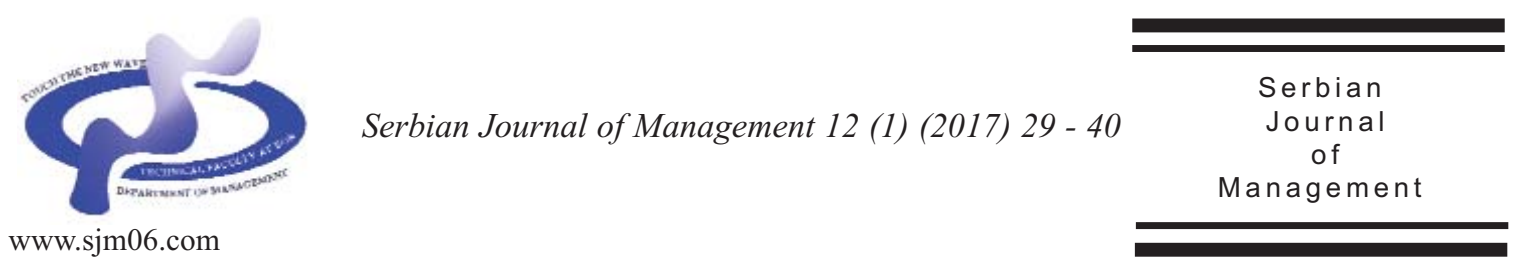

\title{
DETERMINING SUCCESS FACTORS FOR EFFECTIVE STRATEGIC CHANGE: ROLE OF MIDDLE MANAGERS' STRATEGIC INVOLVEMENT
}

\author{
Minhajul Islam Ukil* and Md. Ali Akkas \\ Department of Management, University of Dhaka, Dhaka-1000, Bangladesh
}

(Received 19 July 2016; accepted 20 October 2016)

\begin{abstract}
Middle managers are believed to play most crucial part in strategic change that in consequence leads to organizational success. The present study seeks to identify the underlying success factors for effective strategic change and, to investigate the relationship between middle management strategic involvement and effective strategic change. Data were collected following a survey administered among a group of mid-level managers $(\mathrm{N}=144)$ serving in twenty different private commercial banks in Bangladesh, and analyzed using various statistical tests including descriptive analysis, Pearson correlation, and simple and multiple regressions in STATA. Results uncover that factors like relation with top management, strategy, role and skills are essential for effective strategic change. This study also reveals significant relationship between middle management strategic involvement and effective strategic change. Findings of this research suggest that organizations shall involve mid-level managers to formulate and implement strategy since middle mangers work as a bridge between top management and ground level workers.
\end{abstract}

Keywords: Middle managers, strategic change, strategic involvement, strategic management.

\section{INTRODUCTION}

Managing an enterprise became complex and challenging task due to rapid globalization and increased competition, technological upgradation, and changes in individual and societal behavior. These changes and increased uncertainty in business world intensified the associated business risks, and therefore an organization cannot just rely only on the traditional way to make its business safe (Wheelen \& Hunger,

\footnotetext{
* Corresponding author:minhaj6ukl@hotmail.com
}

DOI: $10.5937 / \operatorname{sjm} 12-11430$ 
2006). The current business realities hold organisations in a state to conceive new approaches and techniques for their effective progress. These approaches and techniques can simply be termed as strategy that is considered as an effective tool for organizational development and long-term competitive advantage (Wheelen \& Hunger, 2006). Strategy is not a one-time activity, and thus organizations need to make continuous, yet systematic and logical changes in their strategy in order to better compete and survive.

Strategy incorporates integrated action plan that once implemented lead to higher margins and facilities to attain sustainable competitive advantage. Ross and Kami (as cited in Fred, 2011) truly said, an organization without a strategy is like a ship without a rudder, moving around in spheres; it has no clear direction to go. Management works to make a better tomorrow for the organizations (Bhandari \& Verma, 2013), and strategy strives to competitive advantage through management activities (Papadakis et al., 1998). However, failing to make judicious changes in strategy may contribute negatively to enterprises, as around seventy percent change programs were explored to be unsuccessful (Aiken \& Keller, 2009). Successful strategic change depends on several factors. In a broad sense, people and engagement are two key factors that affect strategic change (Kash et al., 2014).

Strategy contributes to organizations in several directions by assessing the existing and prospective competitors, instigating new tools and procedures to encounter changed circumstances, environment and new technology (Lamb, 1984). Nonetheless, experts promote huge controversy about the participants in the strategic process. Alkhafaji and Nelson (2004) argue that strategic process consists of the boards of directors, the chief executive officer (CEO), various managers, outside planners and consultants, and sometimes mid-level managers. Though the style of management involvement in the process of strategy varies depending on the nature, size and ownership of the business, middle management plays vigorous role in all phases of strategic process and change (Hoon, 2007, Kuyvenhoven \& Buss, 2011; Mantere, 2008; Solaja et al., 2016).

Many organizations as well as researchers often overlook the involvement of middle management in strategy (Balogun, 2003; Cascio, 1993), and merely focus on top management (Bouquet \& Birkinshaw, 2008). Some other scholars criticize and contend to diminish the role of mid-level managers (Cascio, 1993; Scarborough \& Burrell, 1996). Nevertheless, the concept of middle management still persists, and studies supported the significance of middle management involvement in strategy (Balogun, 2007; Rouleau, 2005). This study aims to provide empirical evidences so as to understand the essence of middle manager's strategic involvement. The specific objectives of this study are: (i) to determine the factors that affect effective strategic change; and (ii) to ascertain the relationship between middle management strategic involvement and effective strategic change.

\section{LITERATURE REVIEW}

Researchers argue that strategy is a process of change (Floyd \& Wooldrdge, 1992) that works as an integrated form (Mintzberg, 1979) in a stream of activities (Mintzberg \& Waters, 1985), which improves continuous learning through the 
involvement of managers at various levels (Mintzberg, 1990). Kuyvenhoven and Buss (2011) derived four key success factors for effective strategic change from Floyd and Wooldridge $(1992,1997)$ : relation with top management, strategy, role and skills. Relation with top management includes recognition of middle management strategic value, good relations with top management and clarification of expectations.

Strategy involves understanding specific directives and strategic rationale behind the plan, involvement in strategic thinking, and commitment to strategy. Role consists of process leadership, authority and freedom to experiment. Skills encompass strategic, leadership, communication and networking skills. Middle managers are defined as the people who coordinate various daily activities of the departments and strategic actions of the hierarchy (Floyd \& Wooldridge, 1994). Likert (1961) described middle managers as 'linking pin', where they coordinate operating and top-level activities.

Floyd and Wooldridge (1992) developed a typology of middle manager's strategic involvement consisting of four factors, which suggests that middle managers are responsible for actions that have both downward and upward influences on organizational strategy. The factors include championing alternatives, facilitating adaptability, synthesizing information and implementing deliberate strategy (Floyd \& Wooldridge, 1992).

Championing alternatives is thought to be an essential function of middle management that refers to the persuasive and persistent strategic communication to top management (Floyd \& Wooldridge, 1992). Study (Burgelman, 1983) found that mid-level managers are often work as a champion of an organization by undertaking initiatives at the functional level. Middle managers become central to all level of an organization, who act as robust promoters and communicators to disseminate solid and persuasive information (Floyd and Wooldridge, 1992). Facilitating adaptability involves information sharing between task forces and facilitating organizational learning in order to make employees competent to adapt to the

\section{Behavioral}

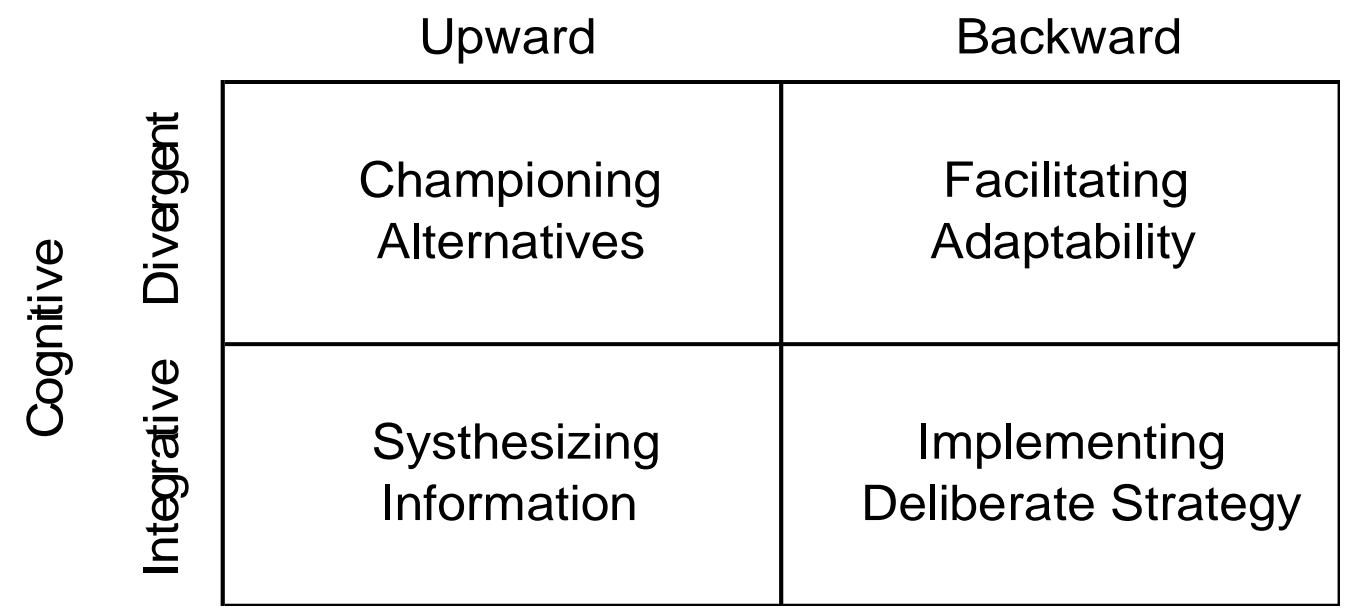

Figure 1. Typology of Middle Management Strategic Involvement (Floyd and Wooldridge, 1992) 
changes (Floyd \& Wooldridge, 1992). Middle managers stimulate reducing conflicting behavior, and make an organization flexible by sharing information and promoting organizational learning (Burgelman, 1983; Kanter, 1983).

Synthesizing information is the exposition and assessment of information affecting the perception of upper management (Floyd \& Wooldridge, 1992). In this way, middle managers influence the strategy formulation upwardly. Mid-level managers are responsible to supply information to upper management (Westly, 1990), and they pervade meaning of information through subjective evaluation and interpretation (Ranson et al., 1980). Implementing deliberate strategy, on the other hand, includes the managerial interventions that align organizational activities with strategic mindset (Floyd \& Wooldridge, 1992). Top management is centrally responsible for implementing strategies though (Kazmi, 2002), mid-level managers play vigorous role in the process of strategy implementation in order to serve specific responsibilities (Bhandari \& Verma, 2013). Top management provides with the necessary instructions, and middle managers implement the anticipated strategies to attain strategic objectives.

Middle managers are found being the key strategic actors in the entire strategic process, and act as both receivers and implementers of strategic change because of their responsibility and position in the organization (Balogun, 2003; Floyd \& Wooldridge, 1994). Middle management contributes significantly to strategy by selling strategic matters to upper management (Dutton \& Ashfold, 1993). Researchers found that mid-level managers influence both the strategy formulation and implementation process (Hornsby et al., 2002). Although the responsibility of top management in strategy implementation is highly significant (Kakabadse \& Kakabadse, 2000), independent strategic actions of middle managers significantly influence the success of an organization too (Burgelman \& Grove, 1996).

The research model of this study was outlined as in Figure 2 based on the prior discussions. On the basis of Middle Management Strategic Involvement typology, a general hypothesis was formulated as follows: "Middle management strategic involvement positively leads to effective strategic change".

\section{RESEARCH METHODOLOGY}

\subsection{Sample and Procedure}

The researchers randomly identified 20 private commercial banks (PCBs) located in Dhaka, the capital city of Bangladesh. A total of one hundred seventy questionnaires were disseminated among branch managers and departmental heads of selected banks, where 144 complete responses were received with a response rate of just over $82 \%$. All questionnaires were distributed and collected manually.

Middle management Strategic Involvement

Effective Strategic Change

Figure 2. Research Model 
As expected, a vast majority of the respondents were male. Only below 5\% of the participants were female. This statistics indicate a significant lower participation of women in management level in the private commercial banks in Bangladesh. Approximately thirty five percent respondents belong to the age category 41-45 years. About thirty one percent respondents were aged between 36 and 40 years whereas over fifteen percent of them were aged between 31-35 years. All participants in the survey were found being married and aged between 31 and 50 years, and have either a postgraduate or a professional degree.

\subsection{Measures and Instruments}

A questionnaire consisting of two sections was designed to collect survey data. One section was developed adopting items from two previous studies, and another section was devised incorporating demographic variables. In order to assess strategic involvement of middle managers, 16 items were taken from the study of Floyd and Wooldridge (1992). Items of the middle management strategic involvement (MMSI) measure pertained to four subscales: championing alternatives (e.g. I am involved to evaluate the merits of new proposals), facilitating adaptability (e.g. Top management encourages informal discussion and information sharing), synthesizing information (e.g. As a middle manager, I communicate the activities of competitors, suppliers etc. to top managers) and implementing deliberate strategy (e.g. Middle managers sell top management initiatives to subordinates).

In addition, based on the construct developed by Kuyvenhoven and Buss
(2011), 13-item statements were phrased to determine the success factors for effective strategic change (ESC). Items of effective strategic change belong to four factors such as relation with top management (e.g. Top managers support me by avoiding conflicting signals about priorities), strategy (e.g. I am encouraged and involved to take part in strategic thinking), role (e.g. I have the authority to take decisions related to my work) and skills (e.g. I try to develop my analytical abilities in order to understand the change context and to manage the implementation of change). Demographic section was devised to understand the general structure of the participants like sex, age, marital status and educational qualification. All the measures except the demographic ones were entirely structured and assessed on a five-point Likert scale ranging between 1-strongly disagree and 5strongly agree.

\subsection{Data Analysis}

Data were analyzed using several statistical methods encompassing descriptive analysis, correlations and regressions analysis in STATA software version 12 for MAC. Descriptive analysis was performed so as to determine the involvement level of mid-level managers in strategy. Pearson correlations, and simple and multiple regressions analysis were done to ascertain the effect of middle management strategic involvement on effective strategic change. To assess the reliability of study variables, scores of Cronbach's alpha coefficients were determined. 


\section{RESULTS}

\subsection{Descriptive and Reliability Analysis}

The summary of descriptive and reliability statistics comprising scores of mean, standard deviation and Cronbach's alpha coefficient of all dimensions of MMSI and ESC have been presented in the following table (Table 1). Table 1 also shows the number of items used for each dimension in order to analyze the perception of respondents about study variables.

Results of descriptive analysis (Table 1) instituted moderate to high scores of mean for all variables used in this study varying between 3.55 and 3.89. Skills $(M=3.89)$ of ESC represented the highest and facilitating alternatives $(\mathrm{M}=3.55)$ of MSI yielded the lowest mean score among all constructs. Mean scores for four dimensions of ESC were found to be highly consistent ranging from 3.78 to 3.89. Overall mean score of MMSI $(\mathrm{M}=3.59)$ was found to be relatively lower than the score of ESC $(\mathrm{M}=3.83)$.

As specified in Table 1, all constructs were evidenced highly reliable for this study as Cronbach's alpha produced higher scores for all variables. Implementing deliberate strategy produced the greatest alpha coefficient of 0.875 among all variables while facilitating alternatives twisted the lowest alpha value of 0.702 . Alpha scores of overall MMSI (0.859) and ESC (0.825) were also explored being high.

\subsection{Correlation Matrix}

Pearson correlations were experimented to explore the standard relationship between constructs used in this study. Products of Pearson correlations between the various dimensions of middle management strategic involvement (MMSI) and effective strategic change (ESC) have been exhibited in Table 2.

Table 2 suggests that all eight constructs of MSI and ESC produced meaningful positive intercorrelations between each other at $p<0.05$. Relationship between championing alternatives and synthesizing information (0.822) produced highest significance among all variables. Championing alternatives also reported moderate uphill correlation with strategy

Table 1. Summary of Descriptive and Reliability Statistics

\begin{tabular}{r|ccccc}
\hline Variable & Obs & Mean & Std. Dev. & Alpha Coef. & No of Items \\
\hline Middle Management Strategic Involvement (MMSI) & $\mathbf{1 4 4}$ & $\mathbf{3 . 5 9}$ & $\mathbf{0 . 4 0}$ & $\mathbf{0 . 8 5 9}$ & $\mathbf{1 6}$ \\
Championing Alternatives (CA) & 144 & 3.61 & 0.49 & 0.779 & 4 \\
Facilitating Alternatives (FA) & 144 & 3.55 & 0.36 & 0.702 & 5 \\
Synthesizing Information (SI) & 144 & 3.64 & 0.47 & 0.717 & 3 \\
Implementing Deliberate Strategy (ID) & 144 & 3.56 & 0.82 & 0.875 & 4 \\
Effective Strategic Change (ESC) & $\mathbf{1 4 4}$ & $\mathbf{3 . 8 3}$ & $\mathbf{0 . 5 0}$ & $\mathbf{0 . 8 2 5}$ & $\mathbf{1 3}$ \\
Relation with Top Management (RT) & 144 & 3.83 & 0.67 & 0.755 & 3 \\
Strategy (ST) & 144 & 3.81 & 0.77 & 0.792 & 3 \\
Role (RO) & 144 & 3.78 & 0.84 & 0.808 & 3 \\
Skills (SK) & 144 & 3.89 & 0.54 & 0.737 & 4 \\
\hline
\end{tabular}


Table 2. Correlation Matrix

\begin{tabular}{|c|c|c|c|c|c|c|c|c|}
\hline & $\mathrm{CA}$ & $\mathrm{FA}$ & SI & ID & RT & ST & $\mathrm{RO}$ & SK \\
\hline Championing Alternatives (CA) & 1 & & & & & & & \\
\hline Facilitating Adaptability (FA) & 0.263 & 1 & & & & & & \\
\hline Synthesizing Information (SI) & 0.822 & 0.214 & 1 & & & & & \\
\hline Implementing Deliberate Strategy (ID) & 0.330 & 0.453 & 0.314 & 1 & & & & \\
\hline Relation with Top Management (RT) & 0.036 & 0.232 & 0.002 & 0.415 & 1 & & & \\
\hline Strategy (ST) & 0.499 & 0.343 & 0.386 & 0.643 & 0.175 & 1 & & \\
\hline Role (RO) & 0.515 & 0.452 & 0.432 & 0.568 & 0.177 & 0.660 & 1 & \\
\hline Skills (SK) & 0.303 & 0.180 & 0.219 & 0.188 & 0.248 & 0.268 & 0.344 & 1 \\
\hline
\end{tabular}

$(0.499)$ and role $(0.515)$ of ESC. In addition, implementing deliberate strategy of MSI constituted higher correlation with strategy (0.643) and role (0.568) of ESC. Strategy and role of ESC are also reported higher internal correlation.

\subsection{Analysis of Simple and Multiple Regressions}

Although correlations statement (Table 2) evidenced significant relationship between middle management strategic involvement and effective strategic change, simple and multiple regressions were also tested to better understand the significance of this relationship determining middle management strategic involvement (MMSI) as independent and effective strategic change (ESC) as dependent variable. Outcomes of simple and multiple regressions have been presented in Table 3 and table 4 respectively.

As displayed in Table 3, analysis of simple regression suggests that middle management strategic involvement positively leads to effective strategic change. This relationship is significant at $\beta=0.888$, Sig $=0.000, p<0.001$, and the relationship impact is reported to be legitimately high since the score of R2 is 0.506 , which implies that middle management strategic involvement predicts and explains over 50\% of the variance in effective strategic change. The beta effect of this relationship $(\beta=0.888)$

Table 3. Results of Simple Regression

\begin{tabular}{|c|c|c|c|c|c|c|c|}
\hline Source & SS & $\mathrm{df}$ & MS & & Number of obs & $=$ & 144 \\
\hline \multirow[b]{2}{*}{ Model } & \multirow[b]{2}{*}{18.0724547} & \multirow[b]{2}{*}{1} & \multirow[b]{2}{*}{18.0724547} & & $\mathrm{~F}(1,142)$ & $=$ & 147.63 \\
\hline & & & & & Prob $>$ F & $=$ & 0.0000 \\
\hline \multirow{2}{*}{ Residual } & \multirow{2}{*}{17.3828465} & \multirow{2}{*}{142} & \multirow{2}{*}{0.122414412} & & R-squared & $=$ & 0.5097 \\
\hline & & & & & Adj R-squared & $=$ & 0.5063 \\
\hline Total & 35.4553012 & 143 & 0.247939169 & & Root MSE & $=$ & 0.34988 \\
\hline ESC & Coef. & Std. Err. & $\mathrm{t}$ & $\mathrm{P}>\mathrm{I} \mathrm{t} I$ & [95\% Conf. & & Interval] \\
\hline MMSI & 0.8884753 & 0.0731228 & 12.15 & 0.000 & 0.7439253 & & 1.033025 \\
\hline _cons & 0.6367013 & 0.2642211 & 2.41 & 0.017 & 0.1143861 & & 1.159017 \\
\hline
\end{tabular}


Table 4. Results of Multiple Regressions

\begin{tabular}{|c|c|c|c|c|c|c|c|}
\hline Source & SS & df & MS & & Number of obs & $=$ & 144 \\
\hline & & & & & $F(4,139)$ & $=$ & 45.44 \\
\hline Model & 20.0916551 & 4 & 5.02291378 & & Prob $>F$ & $=$ & 0.0000 \\
\hline \multirow{2}{*}{ Residual } & \multirow{2}{*}{15.363646} & \multirow{2}{*}{139} & \multirow{2}{*}{0.110529828} & & R-squared & $=$ & 0.5667 \\
\hline & & & & & Adj R-squared & $=$ & 0.5542 \\
\hline Total & 35.4553012 & 143 & 0.247939169 & & Root MSE & $=$ & 0.33246 \\
\hline $\mathrm{ESC}$ & Coef. & Std. Err. & $\mathrm{t}$ & $\mathrm{P}>\mathrm{t}$ & {$[95 \%$ Conf. } & & Interval] \\
\hline $\mathrm{CA}$ & 0.418744 & 0.1017796 & 4.11 & 0.000 & 0.2175077 & & 0.6199804 \\
\hline FA & 0.1844358 & 0.0873256 & 2.11 & 0.036 & 0.0117776 & & 0.357094 \\
\hline SI & -0.1502907 & 0.1053381 & -1.43 & 0.156 & -0.3585629 & & 0.0579814 \\
\hline ID & 0.3197405 & 0.0394705 & 8.1 & 0.000 & 0.2417004 & & 0.3977807 \\
\hline cons & 1.06771 & 0.3229633 & 3.31 & 0.001 & 0.4291547 & & 1.706266 \\
\hline
\end{tabular}

is also pretty high and positive.

Table 4 illustrates the relationship impact of four constructs of middle management strategic involvement on effective strategic change generated through the analysis of multiple regressions. Results indicate that three factors of MMSI namely championing alternatives $\quad(\beta=0.418, \quad \operatorname{Sig}=0.000)$, facilitating adaptability $\quad(\beta=0.184$, $\mathrm{Sig}=0.036)$ and implementing deliberate strategy $\quad(\beta=0.319, \quad \mathrm{Sig}=0.000) \quad$ were significantly related to effective strategic change at $\mathrm{p}<0.01, \mathrm{p}<0.05$ and $\mathrm{p}<0.01$ respectively. Therefore, the hypothesis is accepted.

\section{DISCUSSION}

Mean scores of four success factors suggest that all of these four factors namely relation with top management, strategy, role and skills highly affect effective strategic change. Study (Hrebiniak, 2008) advocates that lack of top management support, vague or poor strategy and lack of understanding of the role resist effective execution of strategy. Therefore, top management should encourage inter-unit cooperation, and empower various managers and employees by providing them with authority to accomplish the desired strategies effectively (DeFeo \& Janssen, 2001).

Results of Pearson correlation, and simple and multiple regressions evidenced significant relationship between middle managers' strategic involvement and effective strategic change. Analysis of simple regression reported a significant impact of middle manager's strategic involvement on effective strategic change, which means middle management involvement in strategy facilitates strategic changes to be effective. This result is consistent with several previous studies (Floyd \& Wooldridge, 1992, 1994, 1997; Kanter, 1983) where the studies recognized middle managers as strategic asset who contribute to strategy and its change 
processes. Balogun (2008) found that middle management has more complex role in strategic change. Storey (1992) moved a step further and argued that middle managers are the agency of change.

According to Schaafsma (1997), middle managers are sometimes forced to change more. Middle management also supports maintaining relationship with external organization like government regulatory bodies, customers and suppliers, which affect organizational change as well (Floyd $\&$ Wooldridge, 1997). Since changes are related to the formulation and implementation of strategy, middle managers should be involved in strategy so that they can facilitate organizational change process effectively (Ekarterini, 2011, Livian \& Burgoyne, 1997). Researchers argue that factors like fear of losing power and authority may resist middle managers to change, and involvement in the various stages of a change process highly influences dedication to change and explicitly lessens resistance (Waddell \& Sohal, 1998).

Newton (2007) found that effective change necessitates adapting the way individuals behave and work. Thus top management shoulders substantial responsibility to make middle managers adaptive by offering informal discussion, relaxing regulations and providing sufficient resources. Although this study established no significant relationship between synthesizing and effective strategic change, many studies uncovered communication to be the most important issue during the change process (Robertson et al., 1993; Postmes et al., 2001). Kotter (2007) viewed under communication as one the key failure aspects of change. As middle management interprets and disseminate information among top managers and subordinates, middle managers should be given enough authority to access and assess organizational information.

\section{IMPLICATIONS LIMITATIONS}

AND

The current study envisioned to ascertain factors relating to effective strategic change, and to determine the impact of middle managers' strategic involvement on effective strategic change. The perception of midlevel managers of private commercial banks in Bangladesh reflected that factors like relationship with top managers, involvement in strategic thinking, clear role, and opportunity to apply skills are necessary for effective implementation of strategic change. This study also found meaningful positive impact of middle management strategic involvement on effective strategic change, which indicates that involvement of midlevel managers in strategic decisions supports organizations to implement strategic change effectively.

The findings of this study contribute to understanding the necessity of middle management involvement in strategy in many folds. Organization can ensure midlevel managers' involvement in strategic decisions through the reassessment of existing policies and applications of new policies and regulations. Another implication of this study is by involving middle managers; top management may overcome the informational gap between workers and higher management.

The present study acknowledges at least two major limitations. One of the key limitations relates to the sample size of this study. The researchers experienced difficulty to find enough mid-level managers as one 
branch of a bank simply employs a very few middle managers. Another significant limitation is the inability to accommodate mid-level managers of state-owned commercial banks (SCBs). SCBs are comparatively bigger than PCBs in terms of number of branches, employees and turnover. Therefore Future researchers may include middle managers of SCBs so as to come up with more generalized results.

\section{References}

Aiken, C., \& Keller, S. (2009). The irrational side of change management. The Mckinsey Quarterly. Number 2.

Alkhafaji, A. F., \& Nelson, R. A. (2003). Strategic management: Formulation, implementation and control in a dynamic environment. Binghamton, NY: The Haworth Press Inc.

Balogun, J. (2003). From blaming the middle to harnessing its potential: Creating change intermediaries. British Journal of Management, 14(1), 69-84.

Balogun, J. (2007). The practice of organizational restructuring: From design to reality. European Management Journal, 25(2), 81-91.

Bhandari, A., \& Verma, R. (2013). Strategic management: A conceptual framework. New Delhi, India: McGraw-Hill Education (India) Private Limited.

Bouquet, C., \& Birkinshaw, J. (2008). Weight versus voice: How foreign subsidiaries gain attention from corporate headquarters. Academy of Management Journal, 51, 577-601.

Burgelman, R. A. (1983). A process model of internal corporate venturing in the diversified major firms. Administrative Science Quarterly, 28(2), 223-244.
Burgelman, R. A., \& Grove, A. S. (1996). Strategic dissonance. California Management Review, 38(2), 8-28.

Cascio, W. F. (1993). Downsizing what do we know? What have we learned? Academy of Management Executive, 7(1), 95-104.

DeFeo, J, A., Janssen, A. (2001). Implementing a strategy successfully. Measuring Business Excellence, 5(4), 4-6.

Ekarterini, G. (2011). A qualitative approach to middle managers' competences. Management Research Review, 34(5), 553575.

Floyd, S. W., \& Wooldridge, B. (1992). Middle management involvement in strategy and its association with strategic type: A research note. Strategic Management Journal, 13(5), 153-167.

Floyd, S. W., \& Wooldridge, B. (1994). Dinosaurs of dynamos? Recognizing middle managers strategic role. Academy of Management Executive, 8(4), 47-57.

Floyd, S. W., \& Wooldridge, B. (1997). Middle manager's strategic influence and organizational performance. Journal of Management Studies, 34(3), 465-485.

Fred, R. D. (2011). Strategic management: Concepts \& Case (13th ed.). New Jersey: Pearson Education Inc.

Hoon, C. (2007). Committees as strategic practice: The role of strategic conversation in a public administration. Human Relations, 60, 921-952.

Hornsby, J. S., Kuratko, D. F., \& Zahra, S. A. (2002). Middle managers' perception of the internal environment for corporate entrepreneurship. Journal of Business Venturing, 17, 233-273.

Hrebiniak, L. G. (2008). Making strategy work: Leading effective execution and change. Pearson Education Inc.

Kakabadse, N., \& Kakabadse, A. (2000). 


\title{
ОДРЕЪИВАЫЕ ФАКТОРА УСПЕХА ЗА ПОСТИЗАЫЕ ЕФЕКТИВНИХ СТРАТЕГИЈСКИХ ПРОМЕНА: УЛОГА СТРАТЕГИЈСКОГ УКЉУЧИВАҢА МЕНАЏЕРА СРЕДЫЕГ НИВОА
}

\author{
Minhajul Islam Ukil, Md. Ali Akkas
}

\section{Извод}

Постоји мишљење да менаџери средњег нивоа имају најзначајнију улогу у стратегијским променама, што као резултат доводи до организационе успешности. Ово истраживање има за циљ идентификацију значајних фактора успеха за постизање ефективне стратегијске промене, као и изучавање повезаности стратегијског укључивања менаџера средњег нивоа и ефективности промена. Подаци су сакупљени применом анкете која је укључила групу менаџера средњег новоа $(\mathrm{H}=144)$ који су ангажовани у двадесет приватних комерцијалних банака у Бангладешу. Потом је анализа урађена применом различитих статистичких тестова, укључујући дескриптивну статистику, пеарсонову корелацију, као и једноставну и вишеструку регресиону анализу у програму СТАТА. Добијени резултати показују да су фактори: однос са топ менаџментом, стратешке улоге и вештине; најзначајнији за ефикасну стратегијску промену. Ова студија такође показује и високу повезаност између стратегијског укључивања менаџера средњег нивоа и ефективне стратегијске промене. Резултати истраживања сугеришу да организације требају да укључе менаџере средњег нивоа код формулисања и имплементације стратегије, обзиром да овај ниво менаџера ради као спона између менаџмента највишег нивоа и оперативног менаџмента.

Кључне речи: Менаџери средњег нивоа, стратегијска промена, стратегијско укључивање, стратегијски менаџмент

Critical review-outsourcing: A paradigm shift. J. Management Develop., 19(8), 670728.

Kanter, R. M. (1983). The change masters. New York: Basic Books.

Kash, B. A., Spaulding, A., Johnson, C. E., \& Gamm, L. (2014). Success factors for strategic change initiatives: A qualitative study of healthcare administrators' perspectives. J Healthc Manag, 59(1), 65-81.

Kazmi, A. (2002). Business policy and strategic management (2nd ed.). New Delhi, India: Tata McGraw-Hill.

Kotter, J. P. (2007). Leading change: Why transformation efforts fail. Harvard Business Review, 2007(January). Retrieved from
http://www.sbshrm.org/uploads/Presentation s/leading_change.pdf

Kuyvenhoven, R., \& Buss, C. W. (2011). A normative view of the role of middle management in the implementation of strategic change. Journal of Management and Marketing Research, 8(1), 1-14.

Lamb, R. (1984). Boyden competitive strategic management. Eaglewood Cliffs, NJ: Prentice-Hall.

Likert, R. (1961). New Pattern of management. New York: McGraw-Hill.

Livian, Y. F., \& Burgoyne, J. G. (1997). Middle managers in Europe. London: Routledge.

Mantere, S. (2008). Role expectations and 
middle managers strategic agency. Journal of Management Studies, 45, 294-316.

Mintzberg, H. (1979). The structuring of organizations. Eaglewood Cliffs, NJ: Prentice Hall.

Mintzberg, H. (1990). The design school: Reconsidering the basic premises of strategic management. Strategic Management Journal, 11(3), 171-195.

Minztberg, H., \& Waters, J. A. (1985). Of strategies, deliberate and emergent. Strategic Management Journal, 6(3), 257-272.

Newton, R. (2007). Managing change step by step: All you need to build a plan and make it happen. Pearson Education.

Postmes, T., Tanis, M., \& de Wit, B. (2001). Communication and commitment in organizations: A social identity approach. Group Process and Intergroup Relations, 4(3), 207-226.

Ranson, S., Hinings, B., \& Greewood, R. (1980). The structuring of organizational structures. Administrative Science Quarterly, 25(1), 1-17.

Robertson, P. J., Roberts, D. R., \& Porras, J. I. (1993). Dynamics of planned organizational change: Assessing empirical support for a theoretical model. Academy of Management Journal, 36(3), 619-634.

Rouleau, L. (2005). Micro-practices of strategic sense making and sense giving: How middle managers interpret and sell change everyday. Journal of Management Studies, 42(7), 1413-1441.

Scarborough, H., \& Burrell, G., (1996). The axeman cometh: The changing role and knowledge of middle managers'. In S. Clegg and G. Palmer (eds.), The politics of management knowledge. Thousands Oaks: Sage.

Schaafsma, H. (1997). A networking model of change for middle managers. Leadership and Organizational Development
Journal, 18(1), 41-49.

Solaja, O.M., Idowu, F.E. \& James, A.E. (2016). Exploring the relationship between leadership communication style, personality trait and organizational productivity. Serbian Journal of Management, 11(1), 99-117.

Storey, J. (1992). Development in the management of human resources. Oxford: Blackwell.

Waddell, D., \& Sohal, A. S. (1998). Resistance: A constructive tool for change management. Management Decision, 36(8), 543-548.

Westly, F. R. (1990). Middle managers and strategy: Microdynamics of inclusion. Strategic Management Journal, 11(5), 337351.

Wheelen, T., \& Hunger, D. (2006). Strategic Management and business policy (12th ed.). New Jersey: Pearson Education. 